\title{
Dionysius on the Problem of Evil: Lessons One can Learn
}

\author{
Jijimon Alakkalam Joseph
}

The problem of evil is a much-debated issue and is as old as human history itself. Evil is a universal and the most common experience of humans, in the sense it functions as a common denominator and no one escapes. Evil causes a sense of isolation. This is evident in the lives of theists. Evil isolates humans from God. Evil is also one such experience that is personal and existential. Evil brings along a lot of meaninglessness. Here it expresses itself as victimization.

As experiences of evil differ, so too the approaches to it. Many attempts have been made - philosophically and theologically - to find a satisfactory solution to this problem. Some approach evil as an intellectual problem, while for others it is existential. Intellectually, the problem of evil is concerned with how to give a rational explanation that reconciles the existence of evil with the existence of an omnipotent, omniscient and omni benevolent God. Existentially, the problem of evil challenges us to console those who suffer and to help them to find some sort of meaning in tragedies that they encounter. No matter how one approaches it, for anyone who reflects on the meaning of life, the problem of evil is fundamental and inescapable.

For our theist ancestors, the problem of evil did not pose a threat to the existence of God. They by and large accepted evil as part of God's plan. Theists offer many solutions to the problem of evil. An exhaustive study of each solution is beyond the scope of this paper. However, I will make a very brief mention of the most significant and historically influential solutions. They are the contrast and the nonintervention solution, evil as punishment for sin, evil as test of

* Department of Religious Studies, Fu Jen Catholic University, Taiwan; jijinde@gmail.com 
man's faith, evil as God's warning, the character building theory, this world is the best of all possible worlds even though evil is a necessary ingredient of it, the free-will argument and the ultimate harmony solution (Madden 1964i).

As human beings evolved, the understanding of evil too changed. Today we live in a world where evil - both material and moralii grows luxuriantly. Many have argued that there is a logical inconsistency between the existence of God and of evil (Madden 1964; Martin 1978). The argument can well be summarized as follows:

a) Evil is something which requires an explanation, and the best available explanation include (or entail) that God does not exist.

b) We can directly (immediately, intuitively) see a support relationship between the existence of evil and the nonexistence of God.

c) Our inability to resolve the prima facie conflict between the existence of evil and the existence of God is best explained by rejecting that God exists. (Pargetter 1976 iii, 243).

The problem of evil has been of concern to theologians of all religious traditions. It is not accidental. The question of meaning, ultimate meaning, is central to all religious traditions. Meaninglessness is one of the greatest threats to religion. As mentioned earlier, existential experience of evil makes life meaningless.

Traditional Judeo-Christian apologists too have vehemently attempted various ways to come to grips with the problem of evil. Among them Dionysius the Areopagite iv deserves special mention. As is well known, his ideas have influenced thinkers of both philosophy and theology at every age (Coakley 2009; Leclercq 1987; Froehlich 1987). There is a plethora of writings on Dionysius and his various ideas.

This paper is not a systematic and thorough study of the ideas of Dionysius on the problem of evil. Rather, I will try to pull out those arguments from Dionysius's discussion on the problem of evil in his treatise The Divine Namesv, which will help us to understand the 
evil of our own time. My reflections are not philosophical, but human and existential. In accordance with the task at hand I will agree or disagree with Dionysius's ideas where necessary.

In his treatise on The Divine Names (hereafter DN) immediately after the completion of his account of God as Goodness, Light, Beauty, Love, Ecstasy and Zeal, Dionysius takes up the problem of evil. Many scholars find the placement of "this awkward, exhaustive, and at first sight somewhat malapropos discussion" (Schäfer 2006, 134) on evil baffling. Dionysius's discussion occupies about one sixth of the whole treatise, and occurs immediately after the discussion on the Goodness of God. There are many reasons for this bafflement. First, for both Dionysius and the Platonic tradition, God is undivided Goodness and is not the source of evil. Second, all the other themes in DN, except the problem of evil, are interconnected. Third, the treatise of evil in DN is not authentically 'dionysian'. It is very similar to Proclus's treatise of evilvi.

Christian Schäfer answers the question of the placement of the problem of Evil in DN as follows:

Its (problem of evil) simultaneous philosophically completely natural and yet 'theonymically' out-of-place discussion (the annoying necessity of what is mirrored by Dionysius's indirect stylistic treatment) reacts to the itch of the age-old trilemma of monistic theodicies: how to maintain that (1) there is only one almighty Creator of all (DN 720B), that (2) He is Good (cf. DN 716BC, 720B), and that (3) evil nevertheless cannot be denied (cf. DN 716B). (Emphasis mine) (Schäfer 2006, 135).

Firstly, the placement of the discussion of evil in DN is seen as a philosophically completely natural way of dealing with the age-old dilemma: How to reconcile the co-existence of God and evil? "A consistent monistic theory of worldly reality that does not want to be diminished or endangered by the paradox of evil cries out loud for a discussion of the problem (of evil), and all the more in a theoontology that defines the entire world as being God's translucent Goodness" (Schäfer 2006, 134). Thus the treatise on evil is an unavoidable parenthesis to the discussion of God. 
Secondly, it is an annoying necessity. As humans we are faced with the problem of evil. "In the realm of being to which we belong as earthly beings and which Dionysius accepts to be God's creation, evil is perceived as a fact" (Schäfer 2006, 134). After listening to a well-structured philosophical discourse on the existence of a Good God, it is natural and human to raise questions about the experience of evil (DN 418 716A vii). Thus I believe the placement of the treatise on evil that immediately succeeds the discussion on the Goodness of God in DN is not an accident, but a well-structured philosophical treatment of the topic.

The bulk of Dionysius's treatise on evil concerns the question: Does evil really exist? The first reading of DN answers this question in a very confusing manner. In some places he says "evil is not a being... Nor is it a nonbeing" (DN 4 19 716D). Elsewhere he says "hence one must concede that there is something contrary to goodness, and that this is evil... Therefore evil is a being" (DN 419 717A). In DN 432 732C Dionysius says "we have to assume that evil exists as an accident" which is immediately succeeded by "given the fact of Providence, how can there be evil?" (DN 433 $733 \mathrm{~A}$ ). There are many such passages in DN which seem very vague and in opposition to each other. Schäfer points out this vagueness as follows: "Evil is not nothing at all nor entirely nonexistent, since as Dionysius observes, it would be futile to beware of or to fight against nothing. Yet, we obviously, and with good reason, obviate, flee and combat evil... Rather, evil is not something in itself; it is not a substance, not a being in its own right. One may still ask what that means." (Emphasis mine) (138).

But a thorough analysis of Dionysius' discussion of evil shows that evil is ultimately non-being because for Dionysius all that exists comes from the Good. Dionysius puts it as: "All beings, to the extent that they exist, are good and come from the Good... That which is totally bereft of the Good never had, does not have, never shall have, never can have any kind of being at all" (DN 420 720B) “... For that which totally lacks a share in the Good has neither being nor a place in existence" (DN 420 720D). The world that truly exists is divine and comes from the Good. Ontologically evil is not a being, "for if it were, it would not be totally evil" (DN 419 $716 \mathrm{D})$, because all that have being come from the Good and 
essentially is good. Evil is not "a nonbeing, for nothing is completely a nonbeing, unless it is said to be in the Good in the sense of beyond-being" (DN 4 19 716D).

Evil as non-being is not an authentically Dionysian concept. His treatise on evil "seems to be directly dependent on Proclus's monograph On the Existence of Evilsviii (Wear 2007, 75), although with alterationsix (Perl 2007, 35; Wear 2007, 75). Proclus is very philosophical in structuring his arguments. But very often Dionysius simply states his views on evil. Dionysius re-arranges, simplifies and Christianizes Proclus' arguments. It is not a comparative study of Proclus and Dionysius. However I will make a mention of the verbal and conceptual similarities between the two wherever necessary.

Dionysius agrees with Proclus that evil is ultimately non-being and there is nothing inherently/wholly evil. All that exists should have something of the Good within it which enables it to exist (DN 419 716C; DN 420 720B). "There is nothing entirely or strictly evil (DN 721A) since total privation is ontologically impossible, and whatever is or can be ontologically 'addressed,' is good at least to a minimum measure. Evil cannot 'be,' nor be thought of, without presupposing good.... Evil per se does not exist and has no rightful ontological status whatsoever (DN 721B) (Schäfer 2006, 139-40).

Evil is not in Good either absolutely or at some stage in time, is not divine and does not come God (DN 421 724A). If evil does not have ontological existence then it could not be in any realm of beings $^{x}$ (DN $421721 C$ ). Evil is not in angels since as images of God they only announce the Good even though the punishment they convey may seem evil to us (DN 422 724B); not in devils because they are not evil by nature. Their evil consists rather in the lack of the angelic virtues (DN 423 724CD, 725B); not among irrational animals who roar or bark because of natural qualities that have their own good purposes (DN 425 728B); not in nature because evil of nature is against nature (DN $426728 \mathrm{C}$ ); and not in our bodies, "for ugliness and disease are an effect in form and a lack of due order" (DN 427 728CD). Nor do bodies cause evil in souls, for evil does not need a body nearby, as seen in the case of demons. In minds, souls and bodies evil is a weakness and defect (DN 424 $725 \mathrm{D}, 728 \mathrm{~A}$ ). Matter too is not evilxi because matter "has a share in 
the cosmos, in beauty and form" (DN 428 729A). For Dionysius "matter is a necessity for the fulfillment of the whole cosmos" (DN $428729 \mathrm{~A}$ ). But this statement is not supported with any proof or argument (Wear 2007, 82). Dionysius agrees that there is no evil in the nature of the universe as a whole; rather it exists in particulars. Goodness is present in all these things in proportion to their capacity to receive it (DN 420 717D, 720D). Beings are evil in so far as they do not act appropriately to their natural virtues and thus are unable to reach their natural state of perfection.

If evil is not a being and has no positive or ultimate existence, how are we to account for the existential human experience of evil? How can evil - which has no being (DN 434 733C), no substance (DN 4 $31732 \mathrm{C}$ ) and "is itself has neither being, goodness, the capacity to beget, nor the ability to create things which have being and goodness" (DN 420 717C) - deprave naturally good being and deprive being? (DN 419 717AB). Dionysius himself presents this dilemma through a fictitious interlocutor:

How is it that the demons whose origins lie wholly in the Good are themselves not shaped like goodness?... What was it made them evil? What in fact is evil? Where did it come from? And where is it to be found? How it was that Goodness itself willed it to be there? ... If evil comes from a different cause, what other cause can there be for things except the Good? If there is any providence at all how can it be that there is evil... And how could anything choose it in preference to the Good? (DN 418 716AB).

Dionysius answers these questions by borrowing the privation theory of Proclus, who based his arguments on the foundations of theory of evil established by Plotinus. Plotinus and Proclus, both Neo-Platonists, agree that there can be no absolute evil and evil is privation and lack of goodness xii. "Whenever we face evil, it is not due to some positive force or power..., but rather to some weakness... The important thing here is that evil is not described as a substantial 'something' or 'entity' but as a circumstance or a coming-to-pass ... which is con-extensively due not to the positive agency of substances (as are their forces and powers) but on the contrary to some weakness, some deficit or incapacity that they have" (Schäfer 2006, 142). 
What is the nature and mode of existence of evil? Dionysius describes evil as "a weakness and a deficiency of the Good" (DN 4 30 732B) xiii. Evil as partial privation of goodness finds its place throughout his doctrine of evil. "Evil...is weakness, impotence, a deficiency of knowledge, of ceaseless knowledge, of belief, of desire, and of activity of the Good (DN 435 736A). "Evil is contrary to progress, purpose, nature, cause, source, goal, definition, will, and substance. It is a defect, a deficiency, a weakness, a disproportion, a sin. It is purposeless, ugly, lifeless, mindless, unreasonable, imperfect, unfounded, uncaused, indeterminate, unborn, inert, powerless, disordered. It is errant, indefinite, dark, insubstantial, never in itself possessed of any existence" (DN 432 732D).

For Proclus "evil is a parasitic entity...which can only survive when mixed with things" (Wear 2007, 80) and it exists accidently and is without efficient cause and indefinite (Wear 2007, 80). Dionysius borrows these ideas. However, evil as a 'parasitic entity' finds its expression only three times in Dionysius. "In DN 732C, Dionysius describes evil as 'existing by means of something else', $\ldots$ in DN 720D in reference to the mode of existence of a disease, and in DN 728D, where evil has a contingent existence, being parasitic even without a body" (Wear 2007, 80). In all the other places evil is presented "as a deficiency in a subject's ability to participate in the Good" (Wear 2007, 80). Although both Proclus and Dionysius agree that evil is a deficiency, Dionysius simplifies and Christianizes Proclus' arguments. "For Proclus, the agent, mistaking the Good, acts in such a way that evil becomes intermixed with being; evil uses a mistaken understanding of the Good as an opportunity to attach itself to being as a parasite. Dionysius, on the other hand, attributes evil to an agent's inability to participate in the Good - hence evil is an insufficient level of Good" (Wear 2007, 81).

God created intelligent creatures with a free will to participate or not to participate in God. The lack of participation in God can be intentional or unintentional (DN $435736 \mathrm{AB})$. When creatures break away from God, they witness no divinization, no life and no being which bears any real likeness of God (DN 27 645B). Thus privation of Good in rational beings is attributed to their 
deviation/move away from what befits them; to their weakness regarding their natural activity (DN 423 725B). "The natural activity of any being is its reversion, its mode of being, of desire for God. A thing's lack of its proper perfections, which qualifies it as evil, is a failure of this desire, and therefore a deficiency of being" (Perl 2007, 59-60). Evil has its origin in this "false conversion" (Riordan 2008, 137). "Evil is a metaphysical reality of willful selfdeprivation from participation in God" (Kharlamov 2009, 223). "The cause for this denial and craving, however, is found in free creatures solely, not in the One that confers this freedom to them" (Schäfer 2006, 147).

Thus Dionysius says that demons who draw not only their existence but also their life (DN 62 856C) and their intelligence (DN 72868 ) from the Good are evil to the extent they fall short of goodness or "by virtue of their inability, as scripture puts it, "to hold on to their original source'" (DN 423 725A). They are not evil by nature. "The evil in demons lies in opposing a mind shaped by goodness" (DN 432 733A). For Dionysius, evil in demons is a deprivation, an imperfection, a powerlessness and the lack, the abandonment and the rejection of the angelic virtues which are appropriate to them (DN 423 725BC). Demon "stupidly has no idea how to obtain what it really wants and indeed does not want it" (DN 72 868C). "Devils are, thus, not evil with respect to their being, but in their failed activity or lack of participation in God" (Wear 2007, 83). Devils cannot be evil because evil is impermanent, but devils are always in the same condition (DN 423 725AB).

Nature is not evil. "Evil in the domain of nature is against nature, a deficiency of what should be there in nature. Thus, there is no evil nature, for this is evil to nature. Rather, evil lies in the inability of things to reach their natural peak of perfection" (DN 426 728C). "Evil in minds, in souls, and in bodies is a weakness and a defect in the condition of their natural virtues" (DN 427 728D). "The evil in the soul lies in the activity contrary to reason" (DN 432 733A). "The evil in the body lies in the renunciation of what is natural" (DN 432 733A). In short, “Dionysius's doctrine of evil as non-being must be understood in the light of the principle that any being is in virtue of its proper determination or perfections, which are its way of being good and therefore its mode of being. Anything is evil, i.e. 
not good, then, insofar as it lacks the proper goodness which is its proper constitutive determination, and to that extent fails to be itself and so to be" (Perl 2007, 58).

As we have already seen, evil cannot be in any realm of being because all things that have being "desire for the Beautiful and the Good ... all their actions are done for what seems to be good...all their intentions have the Good as their source and goal (for nothing does what it does while looking at the nature of evil)" (DN 419 716C). To put in other words, "the Good must be the source and the goal even of what is evil for all things good and bad are for the sake of the Good. Even when we do (wrong) we do so out of our longing for it since there is no one who deliberately does wrong for the sake of wrong" (DN 431 732B). Since all beings ultimately desire good, evil cannot be a motivating force and cannot be the cause of any activity. There is no positive activity that is evil.

For Dionysius, evil - as non-being, as inactivity, as having no substance - is without cause. "The Cause for all good things is one. If, however, evil is contrary to the Good, then evil must have numerous causes. And it is not principles and powers which produce evil but impotence and weakness and an inharmonious commingling of discordances" (DN 431 732B). "Good comes from the one universal Cause, and evil originates in numerous partial deficiencies" (DN 430 729C). The origin of evil "is due to a defect rather than to a capacity" (DN 434 733C). Thus Dionysius concludes, "Evil exists as an accident" (DN 432 7332C).

Evil does not come from the Good (DN 419 716B, 21 724A). If it were to come from the Good, it would not be evil. "Fire cannot cool us, and likewise the Good cannot produce what is not good" (DN 4 19 716B). "Nor will evil itself exist if it acts as evil upon itself, and unless it does this then evil is not entirely evil but has something of the Good within it which enables it to exist at all" (DN 419716 C). Dionysius compares evil with disease. "Disease is a disorder and yet it does not obliterate everything since if this were to happen the disease itself could not exist" (DN 420 720C). "Just as a disease, which kills its host destroys itself, so too, if a being were completely evil, totally devoid of goodness, it would not be an evil being, but would simply not be all, and so would be neither evil nor good" (Perl 2007, 57). 
Dionysius ends his discussion on evil stressing the fact of Providence. How could a providential God permit any degree of evil in the universe? He responds that Providence "knows evil under the form of good" (DN 430 729C) and "even makes good use of evil effects to turn these or others to good use individually and collectively" (DN 433 733B). Evil comes into being "for the sake of the Good" (DN 431 732C). Therefore, for Dionysius, "the Good must be the source and the goal even of what is evil for all things good and bad are for the sake of the Good" (DN 431 732B). "The reality of evil is almost like a barely visible shadow that becomes totally transparent in the rays of divine presence" (Kharlamov 2009, 224). Here Dionysius adds something extra that is not found in Proclus - the concept of free willxiv. "Therefore we should ignore the popular notion that Providence will lead us to virtue even against our will. Providence does not destroy our nature. Indeed its character as Providence is shown by the fact that it saves the nature of each individual, so that the free may freely act as individual or as groups" (DN 433 733B). "This freedom, in its highest degree, includes the possibility of the negation of the good" (Schäfer 2006, 147). "The concluding comments, and supporting scriptural passages, shift the responsibility for evil from God's providence to human freedom. This may seem to preserve God's justice ... , but the evasive argument is not really supported with any discussion of free will itself" (Rorem 1993, 153).

Another question taken up by Dionysius for discussion is why and how beings fail to possess goodness in its fullness. It is here Dionysius's doctrine of reversion comes into play. It is the natural activity of any being. To be is to love God and to desire him. "To be is the activity of a being; and therein lies the possibility of evil" (Perl 2007, 59). Possessing goodness is not a passive reception but needs active co-operation and participation from the part of being.

In his long parenthesis about the problem of evil, Dionysius holds that creation is basically and entirely good and would continue to be so provided creatures act positively. "That which we call evil in the world is merely a tendency of things toward nothingness" (Rolt 1920, 20). However there are many who criticize Dionysius for explaining away evil and thus fail to see the existential human experience of evil. "He is so dazzled with his vision of ultimate 
Reality that he does not feel with any intensity the partial realities of this finite world" (Rolt 1920, 21). But others consider the criticisms of Dionysius positively. For them "any satisfactory account of evil must enable us to retain our outrage at it" (Perl 2007, 64). And so if Dionysius' treatment of evil has evoked criticism, sparked controversies and initiated further discussions that means Dionysius was successful in his endeavor. He made use of the philosophy of the time to explain something that is important to his religious faith. Can we do the same in our own times?

There is no doubt he offers an intellectually sound treatment of the problem but experientially it is hard to understand and accept. Given the fact of the existential experience of evil and human suffering, it is, humanly speaking, hard to accept that evil is nonexistent. If evil is non-existent, how are we to understand wars that have shed blood, the shooting of innocents, rape of the vulnerable, killing in the name of faith? The list could go on. If natural catastrophes are merely 'natural', why do they shatter the human spirit? Many scientific explanations are given, but how many are truly meaningful? As I mentioned at the beginning, down the ages attempts have been made to explain evil and the experience of suffering, though with little success. If evil is non-existent, why did/do humans waste so much energy and time discussing something that does not exist?

The privation theory of evil - evil is a weakness and deficiency of Good - is another argument that does not sell that easily. If evil is considered as a weakness and deficiency of Good, why did the Good God create such a world? Being omnipotent He should have created a perfect world. How can one attribute the evil behavior of humans to mere weakness?

The claim that evil, as non-being and as inactivity, has no cause is another argument that is highly unsatisfactory. Once again philosophically we can explain this position and say that "Dionysius' inability, or rather refusal, to assign a cause to evil, then, marks not the failure but the success of his treatment of the problem" (Perl 2007, 63). But for the average human being, evil exists, and not as an accident, and so it must have a cause or many causes. But the inability to explain those causes is frustrating. 
People have also questioned the concept of free will. Freedom, no matter how it has been interpreted/misinterpreted in human history, is something everyone likes to have and exercise. But faced with harsh experiences of evil, people often ask why "creatures are given freedom anyway, if this implies the possibility of evil?" (Schäfer 2006, 147). People have rational answers to this as well. "God, the perfect, could not, being perfect, create a world less than perfect... A creature capable of deciding and acting on its own account is more perfect (and its actions morally and qualitatively more worthy) than one that cannot do the same thing freely" (Schäfer 2006, 147). But if given a choice between perfection with suffering and happiness without freedom, what will the majority choose? I know it is an absurd question, but I believe the majority would prefer happiness.

Despite much criticism, there are many positive aspects in Dionysius's doctrine of evil that we can accept and appropriate. I do not call them perfect solutions to the problem of evil. But surely they can help us to attribute meaning to our experience of evil. One of the ideas that Dionysius stresses throughout his treatise on evil is that there is nothing inherently/wholly evil. 'Are human beings basically good or evil?' has been a topic for discussion in all philosophies, especially Chinese philosophy. But for Dionysius,all that exists comes from the Good and so is good. No one is born evil. I personally believe that one becomes evil in the process. There are many factors that contribute to it - social, religious, economical, emotional... If one has become evil, all humanity contributes to that directly and indirectly. Consider for example the incident that shook India as a nation in 2012 - the rape of a young girl in a running bus. Having done this inhuman act, the perpetrators threwher out of the bus. Within weeks the victim died in a hospital in Singapore. Or the ISIS crisis that is unfolding in recent times. Those who commit these heinous crimes deserve properly severe punishment. Having said that, I am surprised that no one asked the question, 'what made these people do such an evil act?' Ultimately they are to be blamed, but 'only' they? Are those who commit inhuman acts born evil? For me the answer is no. Victimizers have a past to which many are a part. All have contributed positively or negatively, directly or indirectly. In that sense we all bear the burden of guilt of every evil act done in the world. Dionysius's 
stand that everything is inherently good should help everyone to reflect more on one's responsibility towards the other. Even though evil in the world saddens us, still we can be agents of hope like young Ann Frank who said, “it's a wonder I haven't abandoned all my ideals, they seem so absurd and impractical. Yet I cling to them because I still believe, in spite of everything, that people are truly good at heart." She was a victim of World War II and did not survive the holocaust, but her words did.

Dionysius's treatment of the concept of Providence is another important lesson. Although Providence envelops the universe and is available to all, Dionysius stresses the active cooperation and participation of being. It is not a passive reception. Beings also have to play a positive role in 'reversion' to reach their natural peak of perfection. Providence does not destroy nature or, as Thomas Aquinas puts it, "grace does not destroy nature, but perfects it." No one remains evil provided one, out of free will, chooses to love God. Thus Dionysius's doctrine of evil offers the possibility of conversion.

Finally, evil in the world opens our eyes to the fact that we do not perfectly love the Good yet. If all beings actively desire for the Good, how can there be evil? The existence of evil points to the fact that "the world as we find it does not perfectly love God, the Good, the sole end of all love" (Perl 2007, 64).

All these considerations and lessons, however, make sense to a theist. For an atheist, evil in the world still raises many questions for which answers are yet to be found.

\section{References}

Chlup, Radek. "Proclus' Theory of Evil: An Ethical Perspective". The International Journal of the Platonic Tradition 3 (2009): 26-57. Web.http://booksandjournals.brillonline.com/content/10.1163/187254 $708 \times 397405$

Coakley, Sarah \& Charles M. Stang, eds. Re-thinking Dionysius the Areopagite. West Sussex: Wiley-Blackwell, 2009.

D'Orelli, A. "The Problem of Evil". The Journal of Speculative Philosophy 18 (2) (April, 1884): 188-94. 
Farina, John, ed. Pseudo Dionysius: The Complete Works. Mahwah: Paulist Press, 1987.

Froehlich, Karlfried. "Pseudo-Dionysius and the Reformation of the Sixteenth Century". In Farina, John, ed. Pseudo Dionysius: The Complete Works. Mahwah: Paulist Press, 1987. 33-46.

Kharlamov, Vladimir. The Beauty of the Unity and the Harmony of the Whole: The Concept of Theosis in the Theology of Pseudo-Dionysius the Areopagite. Oregon: Wipf \&Stock, 2009.

Leclercq, Jean. "Influence and Noninfluence of Dionysius in the Western Middle Ages". In Farina, John, ed. Pseudo Dionysius: The Complete Works. Mahwah: Paulist Press, 1987. 25-32.

Madden, Edward H. "The Many Faces of Evil". Philosophy and Phenomenological Research 24 (4) (June 1964): 481-92.

Martin, Michael. "Is Evil Evidence Against the Existence of God?" Mind New Series 87 (347) (July 1978): 429-32.

McCloskey, H.J. “God and Evil”. The Philosophical Quarterly 10 (39) (April 1960): 97-114.

O'Brien, Denis. Plotinus on Matter and Evil. Electronically downloaded from http://cco.cambridge.org/uid=21658/ pdf_handler?id=ccol0521470935_CCOL0521470935A009Epdf_hh $=1$ 2006

O'Conner, David. "On the Problem of Evil's Still Not Being What it Seems". The Philosophical Quarterly 37 (149) (Oct 1987): 441-47.

---. "On the Problem of Evil's Still Not Being What it Seems". The Philosophical Quarterly 40 (158) (Jan, 1990): 72-8.

Pargetter, Robert. "Evil as Evidence against the Existence of God". Mind New Series 85 (338) (April, 1976): 242-45.

Pelikan, Jaroslav. The Odyssey of Dionysian Spirituality. In Farina, John ed. Pseudo Dionysius: The Complete Works. Mahwah: Paulist Press, 1987. 11-24.

Perl, Eric D. Theophany: The Neoplatonic Philosophy of Dionysius the Areopagite. Albany: State University of New York Press, 2007.

Pike, Nelson. "God and Evil: A Reconsideration". Ethics 68 (2) (January, 1958): 116-24. 
Pourtless, John A. "Towards a Plotinian Solution to the Problem of Evil". Aporia 18 (2) 2008 http://aporia.byu.edu/pdfs/pourtlesstoward_a_plotinian_solution_to_the_problem_of_evil.pdf

Riordan, William. Divine Light: The Theology of Denys the Areopagite. San Francisco: Ignatius Press, 2008.

Rolt, C.E. Dionysius the Areopagite: On the Divine Names and the Mystical Theology. 1920 http://www.ccel.org/ccel/rolt/dionysius/ Page_i.html

Rorem, Paul. Pseudo-Dionysius: A Commentary on the Texts and an Introduction to Their Influence. Oxford: OUP, 1993.

Santayana, G. "Dr. Fuller, Plotinus, and the Nature of Evil". The Journal of Philosophy, Psychology and Scientific Methods 10 (22) (Oct, 1913): 589-99.

Schäfer, Christian. Philosophy of Dionysius the Areopagite:An introduction to the structure and the content of the treatise on the divine names. Boston: Brill, 2006. http://www.scribd.com/ doc/ 92909888/the-Philosophy-of-Dionysius-the-Areopagite

Wear, Sarah Klitenic \& John Dillion. Dionysius the Areopagite and the Neoplatonist Tradition: Despoiling the Hellenes. England: Ashgate Publishing Limited, 2007. http://www.scribd.com/ doc/ 76924872/ Dionysius-the-Areopagite-and-the-Neoplatonist-Tradition

Wilberding, Erick. A Defense of Dionysius the Areopagite by Rubens. Journal of the History of Ideas 5 (1) (Jan-Mar, 1991): 19-34.

Pourtless, John A. 2008

Problem of

Towards a Plotinian Solution to the _the_problem_of_evil.pdf

Riordan, William.2008

Divine Light: The Theology of Denys the Areopagite. San Francisco: Ignatius Press.

Rolt, C.E.1920 Dionysius the Areopagite: On the Divine Names and the Mystical Theology. http://www.ccel.org/ccel/rolt/dionysius/Page_ i.html

Rorem, Paul.1993 Pseudo-Dionysius: A Commentary on the Texts and an Introduction to Their Influence. Oxford: Oxford University Press. 
Santayana, G. 1913 Dr. Fuller, Plotinus, and the Nature of Evil. The Journal of Philosophy, Psychology and Scientific Methods 10 (22) (Oct): 589-99.

Schäfer, Christian. 2006 Philosophy of Dionysius the Areopagite:An introduction to the structure and the content of the treatise on the divine names. Boston: Brill. http://www.scribd.com/ doc/92909888/the-Philosophy-of-Dionysius-the-Areopagite

Wear, Sarah Klitenic \& John Dillion. 2007 Dionysius the Areopagite and the Neoplatonist Tradition: Despoiling the Hellenes. England: Ashgate Publishing Limited. http://www.scribd.com/doc/ 76924872 /Dionysius-the-Areopagite-and-the-Neoplatonist-Tradition

Wilberding, Erick. 1991 A Defense of Dionysius the Areopagite by Rubens. Journal of the History of Ideas 5 (1) (JanMar): 19-34.

\section{Notes}

${ }^{i}$ In this paper, Madden analyses each of these solutions and concludes "that the problem of evil is insoluble and that this insolubility is a sufficient reason for not believing in any type of theistic god whatever" (481).

iiThese terms are not sufficient to explain the significant differences with clarity (McCloskey 1960, 98).

iii Pargetter is of the opinion "that the existence of evil is strong evidence against the existence of God has not been justified, and ...unsuccessful" (244-5).

iv There are many scholarly speculations about the true identity of Dionysius. For a detailed discussion, see Pelikan 1987; Wilberding 1991.

v Translations of the writings attached to the name of Dionysius the Areopagite are numerous. I have followed the translation edited by Farina, John. 1987. Pseudo Dionysius: The Complete Works. Mahwah. Paulist Press.

vi For the most recent discussion on Dionysius' philosophical dependence on Proclus, see Wear 2007, 75-84.

vii (DN 418 716A) indicates The Divine Names, chapter 4, section 18, and column 716A.

viii This monograph is also called On the Subsistence of Evils (Perl 2007, 53) 
ix For a detailed study of the influence of Proclus on Dionysius, see Wear 2007, 75-84).

x For Proclus, the realm of beings includes "gods, angels, daemons, heroes, souls (Immaculate souls, fallen human souls, irrational souls), nature and matter" (Wear 2007, 83). Dionysius, as a Christian, appropriates this nonChristian hierarchy of being excluding gods, and simplifies the whole argument stating that since everything proceeds from the Good, evil cannot reside at any level of being (Wear 2007, 83).

xi Plotinus holds "that matter is both evil and a necessary consequence of the Good, without which the (good) cosmos could not be produced" (Perl 2007, 58). Proclus rejected this doctrine (Perl 2007, 56).

xii For a detailed explanation, please see Perl 2007 and O'Brien 2006.

xiii Dionysius extends the privation theory to all realms of beings, from angels down to matter. Evil is no positive reality in anything. But it can occur at any level of being. Whereas Proclus applies privation theory only to the realms of human souls and natural bodies (Perl 2007, 58).

xiv Dionysius takes this concept from Origen (Wear 2007, 83). 